\title{
The Uninhabitable Earth: A Story of the Future
}

David Wallace-Wells (2019), The Uninhabitable Earth: A Story of the Future, London: Penguin Books, 320 pp, ISBN: 978-0-141-98887-0 (paperback)

ISBN: 978-0-525-57670-9 (hardback)

\section{Valerie Kay, Climate Change and Public Health, Monash University, Australia}

David Wallace-Wells says that he 'is not an environmentalist' and does not think of himself as 'a nature person' (Wallace-Wells, 2019: 6). However, he collected stories and evidence about climate change for years, and thought that climate change was not receiving the attention it merited. He wrote an article in the New York Magazine in 2017 that generated great interest - and some controversy (Matthews, 2019). He then went on to write The Uninhabitable Earth, which has become a best seller.

The success of the book is a testament to the author's ability to create an effective story about climate change. I teach graduate students about climate change and health, and part of my work involves updating teaching materials to make climate science accessible. I envy the author's ability to create a gripping and coherent narrative; this is particularly seen in Chapters 1 to 12 , which deal with the impact of climate change on heat, hunger, oceans, disasters, air quality, conflict and more.

I was also struck by this statement, made in response to the former governor of California talking about devastating wildfires as a 'new normal':

The truth is actually much scarier. That is, the end of normal, never normal again.

- (Wallace-Wells, 2019: 18)

This particularly hit home because of recent conversations with students about extreme heat, (virtual conversations, of course, as we are in a pandemic of a new zoonotic disease; a phenomenon that is expected to become more frequent due to ecological degradation and climate change; United Nations Environment Programme and International Livestock Research Institute, 2020). Those of us who live in the Asia-Pacific region may think we are used to heat, that we can cope with it. It is hard 
Reinvention: an International Journal of Undergraduate Research 14:1 (2021) to accept that some parts of our region may experience essentially unsurvivable heatwaves this century. (Im, Pal and Eltahir, 2017).

Some climate scientists objected to what they saw as a catastrophic or 'doomist' tone a focus on low-probability worst-case outcomes - in the original 2017 article, and to some extent in the book (Matthews, 2019). There are concerns that scaring people can paralyse them and make constructive action less likely. Wallace-Wells, however, suggests people need to be scared to make them aware.

I have to admit there are some things about this book I do not like. I am not the intended audience, and the good it appears to be doing by informing people about climate change probably far outweighs any concerns I have. Nevertheless, I have some.

When preparing this review, I looked through recent issues of this journal, and saw a review of Invisible Women (Dolamulla and Tosun, 2020), which resonated. One of my concerns about The Uninhabitable Earth is that women are largely invisible in the book.

Gender, and intersectional factors around race, imperialism, class and indigeneity, is very relevant to climate change. Empirically, organisations and societies where women are more involved do more to address climate change (Ergas and York, 2012; Buckingham, 2010; Ben-Amar et al., 2017), while conversely, conservative white men are most likely to be climate change deniers (McCright and Dunlap, 2011). Historically, there is a nexus between capitalism (which the author acknowledges), imperialism and racism (which he partially acknowledges) and patriarchy (which he does not acknowledge) in contributing to ecological degradation. Wallace-Wells cites a key scholar in this area, Carolyn Merchant, but does not mention her work on the nexus of patriarchy and capitalism (Merchant, 1989).

Other concerns are the frequent throwaway digs at 'liberals' and 'progressives' for trying to do something about climate change, and apparent suggestions that individual action is somehow opposed to collective action. (The latter is a persistent and misleading trope in climate discussions, although admittedly this makes more sense in the US where a person might conceivably - at a stretch - feel something like 'I purchase green wellness products in the supermarket, therefore I don't need to vote', than in Australia, where voting is compulsory). The author's tendency to have digs at others may have something to do with his confession in the introduction: 
I toss out tons of wasted food and hardly ever recycle; I leave my airconditioning on; I bought into Bitcoin at the peak of the market - (Wallace-Wells, 2019: 33)

It might have been more enlightening if this confessional theme had been followed through, and the author had examined why he acted like this, rather than expressing apparently patronising views about people trying to do the right thing:

Western liberals have comforted themselves by contorting their own consumption patterns into performances of moral or environmental purity less beef, more Teslas, fewer transatlantic flights - (Wallace-Wells, 2019: 32)

I admit, I am one of the people doing those things (although I do not have a Tesla, or even a car; I have a bike, and it is not even electric, although it is a pretty good bike). But I am not doing this because of moral purity, I am doing it because I would like my children and my grandchildren, and everyone else's, to have a decent - habitable world to live in.

In general, reduction in consumption does not seem to be seriously considered in the book, in spite of evidence that wealthy, high-consuming people are responsible for high proportions of emissions (Ivanova and Wood, 2020). A minor but seemingly telling point is that Dr Jason Hickel, a researcher on sustainable economies, is included in a chapter that focuses on fringe views, even though Hickel is described as an 'incisive' theorist (Wallace-Wells, 2019: 207).

I suggest people read Chapters 1 to 12 to get a gripping picture of what climate change is doing and will do in the future if we don't act as soon and do as much as possible to mitigate it, and then browse the rest of the book for interest. Throughout, however, I recommend ignoring the digs at people who are trying to do something about climate change. The major barriers to action on climate change are political (as the author acknowledges, by urging people to vote), supported by the building coalitions of people who are trying to do the right thing, which seems more useful than patronising them.

\section{References}

Ben-Amar, W., M. C. and P. McIlkenny (2017), 'Board gender diversity and corporate response to sustainability initiatives: Evidence from the carbon disclosure project', 
Buckingham, S. (2010), 'Call in the women', Nature, 468, 502

Dolamulla, R and N. C. Tosun (2020), 'Perez, Caroline C. (2019), "Invisible women (Exposing data bias in a world designed for men)"', Reinvention: an International Journal of Undergraduate Research, 13 (1)

Ergas, C. and R. York (2012), 'Women's status and carbon dioxide emissions: A quantitative cross-national analysis', Soc. Sci. Res., 41, 965-76

Im, E-S., J. S. Pal and E. A. B. Eltahir (2017), 'Deadly heat waves projected in the densely populated agricultural regions of South Asia', Science Advances, 3 (8)

Ivanova, D. and R. Wood (2020), 'The unequal distribution of household carbon footprints in Europe and its link to sustainability', Global Sustainability, 3, 1-12

Matthews, S. (2019), 'The end of the story', Slate, available at https://slate.com/culture/2019/02/uninhabitable-earth-review-david-wallacewells-climate-change, accessed 23 April 2021

McCright, A. and R. Dunlap (2011), 'Cool dudes: The denial of climate change among conservative white males in the United States', Glob. Environ. Change-Human Policy Dimens., 21, 1163-72

Merchant, C. (1989), The Death of Nature: Women, ecology, and the scientific revolution, New York: Harper \& Row

United Nations Environment Programme and International Livestock Research Institute (2020), 'Preventing the next pandemic: Zoonotic diseases and how to break the chain of transmission', Nairobi, Kenya: UNEP

Wallace-Wells, D. (2019), The Uninhabitable Earth: A story of the future, London: Penguin Books

\section{Virginia Thomas-Pickles, University of Warwick}

The title of this book, The Uninhabitable Earth: A Story of the Future, offers a suggestion about the bleak picture its contents will paint. Split into four sections, the book considers the future of human civilisation in this age of climate change. The first section, 'Cascades', sets the scene, discussing increasing greenhouse gas emissions 
Reinvention: an International Journal of Undergraduate Research 14:1 (2021) against the backdrop of unsuccessful climate policies. In this section, Wallace-Wells challenges the idea that carbon emissions are mainly historical, noting that over half of these emissions have been produced since 1992 (p. 4), therefore highlighting how humanity has continued generating carbon emissions, despite being aware of the consequences.

Moving away from downplayed climate-change threats portrayed in the media and politics, this book delves deeper into a wide range of lesser-known impacts alongside the commonly known impact of sea-level rise. Cleverly, scientific concepts are interwoven throughout these threats, explained in an easily accessible way. One impact discussed is the response of bacteria in the human body to changing climatic conditions. Wallace-Wells recounts the unforeseen deaths of saiga (a species of antelope) following intense heat leading to usually harmless bacteria in their bodies overwhelming their organs (pp. 113-14). While some may criticise the presentation of these impacts as alarmist, such shocking details provide a wake-up call to the reader. The full extent of the impact of climate change is unknown - so action is needed now.

Repeatedly, the reliance on technology to offset emissions is discussed. Wallace-Wells argues that technology is not the barrier to action; instead, it is the socio-political will to overhaul current systems. With continually growing societal consumption, technology cannot undo the damage being caused. This critique of reliance on technology, and subsequent failings of societies to change their actions, relates to previous chapters, noting how the need for international governance has not been fulfilled and criticising the failings of international treaties to instigate significant change. This emphasises the central theme of the book: civilisation lacks - and must recognise the urgency of - the collective will needed to change its actions to prevent the severest impacts of climate change. This theme continually incites reflection on current individual lifestyles and on the actions of wider society.

Interestingly, Wallace-Wells devises the term 'Climate Kaleidoscope' to explain how civilisation is 'mesmerised by the threat directly in front of us without ever perceiving it clearly' (p. 143). I find this term enlightening and a true reflection of the problem that society must overcome. This links nicely into the short final section, "The Anthropic Principle', which considers why humanity is aware of the horrors of climate change yet seemingly ignores it. Wallace-Wells argues that society should be empowered to act by the existence of civilisation and how unlikely it was to emerge, thus using collective choices to limit climate change - again returning to the underlying central theme of the book. I had not encountered this argument before and 
was dismissive of it at first, but found that, over time, it really provoked reflection. The Earth will continue with or without humanity, so it is up to us collectively to ensure our civilisation lives on, by taking advantage of the mathematically extremely unlikely existence of mankind, and therefore the unique opportunity we have.

A substantial amount of credible secondary research was conducted in the writing of this book, amounting to 65 pages of references. While I praise this, and many other aspects of the book, I do have one over-arching criticism. Throughout the book, 'we' is used to highlight how everyone is responsible for ensuring that the impacts and suffering climate change will cause do not prevail. While useful for provoking thought, this arguably neglects the marginalisation, unequal voice and unequal contributions briefly touched on at the start of the book. Furthermore, China is repeatedly mentioned as a large greenhouse gas emitter. However, while true, the narrative neglected to discuss the causes of this. It fails to note how a significant proportion of these emissions are exported, driven by the demands of consumption-driven nations such as the US and UK. I feel this is a missed opportunity; such a discussion would have added further weighting to the argument of issues in current societies.

Overall, however, this book is a refreshing take on the climate-change debate. Through his engaging, passionate writing style, Wallace-Wells coherently presents his views on the climate issue. He leaves the reader with optimism that, collectively, we can overcome climate change. This book is a great introduction to the complexities and future consequences of climate change. It also provides an interesting, thoughtprovoking perspective that raises different considerations for those already with insight who want to know more.

To cite this paper please use the following details: Kay, V. OR Thomas-Pickles, V. (2021), David Wallace-Wells (2019), 'The Uninhabitable Earth: A Story of the Future', Reinvention: an International Journal of Undergraduate Research, Volume 14, Issue 1, https://reinventionjournal.org/article/view/724/. Date accessed [insert date]. If you cite this article or use it in any teaching or other related activities please let us know by e-mailing us at Reinventionjournal@warwick.ac.uk. 